https://helda.helsinki.fi

\title{
The Palaepaphos-Laona rampart. A pilot study on earthen architecture and construction technology in Cyprus
}

\section{Lorenzon, Marta}

2019-02

Lorenzon , M \& lacovou , M 2019 , ' The Palaepaphos-Laona rampart. A pilot study on earthen architecture and construction technology in Cyprus ' , Journal of Archaeological Science: Reports , vol. 23 , pp. 348-361 . https://doi.org/10.1016/j.jasrep.2018.11.004

http://hdl.handle.net/10138/325358

https://doi.org/10.1016/j.jasrep.2018.11.004

cc_by_nc_nd

acceptedVersion

Downloaded from Helda, University of Helsinki institutional repository.

This is an electronic reprint of the original article.

This reprint may differ from the original in pagination and typographic detail.

Please cite the original version. 
The Palaepaphos-Laona rampart.

A pilot study on earthen architecture and construction technology in Cyprus

\author{
1.Marta Lorenzon, University of Helsinki, \\ Centre of Excellence in Ancient Near Eastern Empires Marta.Lorenzon@helsinki.fi; \\ mlorenzon854@gmail.com
}

2.Maria Iacovou, Department of History and Archaeology, Archaeological Research Unit, University of Cyprus mariai@ucy.ac.cy

Revised Submission: Journal of Archaeological Science Reports

\begin{abstract}
Excavations conducted in the context of the Palaepaphos Urban Landscape Project (PULP) have revealed a defensive monument of the Cypro-Classical period (fifth and fourth centuries $\mathrm{BCE}$ ), which had been preserved under an anthropogenic mound (tumulus) of the 3rd century BCE. Besides stone-work, the construction of the monumental rampart made extensive use of mudbricks. In 2016-2017, PULP introduced a pilot study based on analytical techniques (pXRF, SEM-EDS, granulometric and petrographic analysis) to address issues relating to the manufacture and construction of the earthen architecture of the rampart. The paper presents a description of the geoarchaeological analyses and their results, which have highlighted specific manufacturing practices in relation to the construction of the monument. Given that the rampart constituted a major investment of the royal authorities of ancient Paphos, the results provide new information on the production of earthen building materials and also on environmental choices with respect to raw material selection in the context of a public project carried out by a central authority circa the mid first millennium BCE.
\end{abstract}

Keywords: Cyprus; earthen architecture; geoarchaeology; granulometric analysis; mudbrick; petrography; $\mathrm{pXRF}$ 


\section{Introduction}

Since the 1980s numerous geoarchaeological studies in the Near East have showcased the importance of earthen architectural analysis not only in relation to the built environment but as an expression of social agency (French 1984; Friesem 2011; Goldberg 1979; Love 2013; Morgenstein and Redmount 1998; Rosen 1986). In the eastern Mediterranean island of Cyprus mudbricks were, and are, an integral part of its architectural identity. While the earliest have been recovered in the context of Neolithic sites (e.g. Aurenche 1981; Love 2012; Philokyprou 1998), mudbricks are still in use today as a key component of vernacular architecture (Costi de Castrillo, Philokyprou and Ioannou 2017; Illampas et al. 2011).

Earlier studies of earthen architecture in Cyprus have focused mainly on 5th and 4th millennium BCE sites (Clarke 2007; Peltenburg 1978; Thomas 1995; Todd 1979), and provided a comprehensive analysis of the architecture (Philokyprou 1998, 2012; Wright 1992: 42, 378-381). Recent geochemical studies of Cypriote earthen building materials focus on their performance and preservation (Costi de Castrillo, Philokyprou and Ioannou 2017; Demetriou et al. 2003). The potential, however, of geoarchaeological research to investigate production, manufacturing and environmental issues regarding raw material selection and motivational choices has been tapped for the first time in the archaeology of Cyprus with the scientific analyses of earthen building materials from the first millennium BCE site of PalaepaphosLaona, currently under excavation. The need to study earthen techniques, and the absence of previous investigations of Iron Age mudbrick architecture on the island, motivated the authors to undertake the research presented here. The impressive mudbrick architecture of a recently discovered Cypro-Classical public monument (Iacovou 2017a) has been sampled and analysed. The results initiate a new research venue in the study of the manufacture and construction technology of earthen architecture in the context of the establishment of a defensive monument by the ruling authorities of the polity of Paphos in the Cypro-Classical period.

\section{Figure 1}

\section{The archaeological context of the case-study: Palaepaphos-Laona}

The Palaepaphos Urban Landscape Project (PULP 2006-2018) is a long-term landscape analysis project initiated in 2006 for the purpose of studying the largely invisible urban structure of Ancient Paphos (Iacovou 2008; Iacovou et al. 2009), one of the most celebrated ancient city-states of the island, better known since the 3rd c. BCE as Palaepaphos (Old Paphos) 
[FIG.1]. In the context of the project, which is also studying the economic territory and potential resources of the ancient polity within the hydrological basin of Paphos (Iacovou 2012; 2014), a number of special function areas were identified to the north and east of the famous sanctuary of the Cypriote Aphrodite, which is situated on the SE fringe of the modern village of Kouklia (Iacovou 2013a). Fieldwork on the plateau of Hadjiabdoulla and the hillock of Laona [FIG.2] revealed the existence of hitherto unknown, and surprisingly well-preserved, Iron Age monuments (Iacovou 2017b; https://ucy.ac.cy/pulp/).

\section{Figure 2}

The most impressive of the new monuments is a man-made mound raised on the natural hillock of Laona. Large mounds (tumuli) are foreign to the material culture of ancient Cyprus. In part, this must be the reason why it was not previously identified, despite its dimensions $(100 \times 60 \times 10$ metres) and high visibility in the landscape [FIG.3].

\section{Figure 3}

Following the confirmation of its antiquity (Iacovou 2017a: 322), a new field project was designed for its investigation, which began in 2012. In order to preserve the better part of this mysterious landscape marker, excavations were concentrated exclusively in the SE quarter of the tumulus [FIG.4].

\section{Figure 4}

During the initial 2012 season trial trenches revealed that the mound was constructed by the consecutive dumping of marl and soil. The fill consists "of horizontal lenses of beige angular marl fragments ... alternating with red relatively massive clay-rich soils" (Karkanas and Goldberg 2019: 219). The source of this material is the local Miocene-Pliocene pelagic sediment bedrock characteristic of the southwestern coastal plains of Cyprus. The thinner layers of soil consist of red clay mixed with gravels and cobbles of exotic lithologies. The source of this material is in the immediate vicinity of the site of the tumulus. More specifically, the marl bedrock is topped by Quaternary fluviomarine gravel terraces consisting of transported materials, later covered by a layer of in-situ formed red soil, a typical Mediterranean landscape component widely known as terra rossa (Zomeni 2012). It has been estimated that the mound 
is made of circa 13.700 cubic metres of soil materials (the calculation was based upon the contour lines from 107-114 meters above sea level, using the method of the average area multiplied by the equidistance between the contour lines). The transported soils contain very few diagnostic artefacts: small sherds, tiny parts of terracotta figurines and some pithos fragments. Ceramic analysis provides a terminus for the construction of the mound, which is currently placed in the 3rd century BCE.

\subsection{The rampart preserved under the Laona mound}

In 2014, an older public monument was found under the thick layers of compact marl and red soil along the east side of the SE quarter of the mound. This is a monumental rampart, whose preservation in height increases from south to north along with the increase in height of the mound itself. On the inner side of the rampart, two staircases facing each other appear to have ascended to towers [FIG.5].

\section{Figure 5}

The pottery from the foundation trenches below the two staircases provides a construction date around the transition from the $6^{\text {th }}$ to the $5^{\text {th }} \mathrm{c}$. BCE. The foundation line of the rampart is at $107.20 \mathrm{~m}$ asl. Hence, at $113.086 \mathrm{~m}$ asl. the maximum preserved height of the rampart at the north-eastern section (excavated in 2017) must reach over six metres [FIG.6]. A fifth-century $\mathrm{BC}$ built monument standing up to six metres in height is certainly unprecedented in Cyprus and extremely rare in the rest of the Mediterranean.

\section{Figure 6}

The date of its construction and its sensitive location $70 \mathrm{~m}$ to the north of what is now identified as the plateau of the contemporary Cypro-Classical citadel on the terrace of Hadjiabdoulla (see Fig.2 above; Iacovou 2017b: 207-209, figs 16-17), would confirm that the project was decided and executed by the ruling dynasty of Paphos (cf. Satraki 2012: 227, 391). As the excavation progresses, the Laona rampart is bound to become the focus of many specialised studies, primarily as regards the style of its architecture and the materials employed for its construction. Besides its historical significance as a major building project of the same royal agency that was also in charge of the megalithic temenos of the Cypriot goddess - the urban focus of the polity since 1200 BC (cf. Hermary 2014; Iacovou 2013b: 152; Maier 1989)- study of the materials, 
in this case the mudbricks, opens up a rare opportunity to understand the manufacturing and building practices of the Paphian builders.

\subsection{Mudbricks and stone work}

Although the excavation of the rampart will not be completed for some time (the north and west sides have not been excavated and the south appears to be completely eroded), a preliminary study of the ground plan of the east side, currently exposed to a length of $63 \mathrm{~m}$, reveals the basic principle behind the implementation of the architectural design: mould-made and perfectly preserved mudbricks are packed between long stretches of stonework. The northeastern section of the rampart, for example, has on the preserved top surface six parallel rows of mudbricks of identical size $(40 \times 50 \times 12 \mathrm{~cm})$, visible on the ground plan [Fig.7]. Evidence for the use of supporting wooden elements has not been observed.

\section{Figure 7}

In the context of the MEANING research project ${ }^{1}$, which has received funding from the University of Cyprus A.G. Leventis Research Programmes, PULP secured a two-year grant (2017-2019) with which to initiate a series of archaeo-environmental data analyses. This included the macroscopic and geochemical analyses of the Laona mudbricks, which was undertaken by Marta Lorenzon. The goal of the pilot study was to identify the mineralogical and chemical composition of the mudbricks. Procurement of raw materials and the characterisation of manufacturing and construction phases were also addressed. The ultimate goal is to establish an interdisciplinary methodology for researching mudbrick manufacturing and construction practices from excavation contexts.

\section{Sampling, Materials and Methods}

Sampling took place in 2016 and the first macroscopic analysis was done in situ. All 34 samples come from the excavated east side of the rampart: PA 1-12, 32-34 were selected from the central area of the East wall against which the two staircases are built [Fig.7]; PA 15-31 come from the exposed NE curved section of the East wall, which is a rare feature in mudbrick architecture (Aurenche 1981: 124; Ginns 2015: 138); finally, two samples (PA 13 and PA14)

\footnotetext{
${ }^{1}$ MEANING stands for the abbreviated reference to the project, From the metalliferous sources to the citadel complex of Ancient Paphos: archaeo-environmental analysis of the mining and the built environment; the project description is available in Iacovou 2017 in Academia.edu).
} 
were collected from the preserved top surface of the mudbricks. The samples were cut and transported for study to the Wiener Laboratory for Archaeological Science, American School of Classical Studies at Athens. Macroscopic and microscopic (i.e. petrographic and geochemical) analyses were conducted on the sample and the combination of their results was then used to answer our research question.

\subsection{Macroscopic analysis}

Macroscopic observations were carried out in the field in 2016 and included the recording of size, colour and fabric for each of the mudbrick samples as well as analysis of the wall structure. The macroscopic fabric was characterised as coarse or fine based on quantity and consistency of inclusions bigger than $2 \mathrm{~cm}$, which consists mainly of pottery and stone fragments (Lorenzon 2017). The colour was determined through the Munsell colour chart (Munsell 1929). The investigation of each mudbrick focused on size, colour and macroscopic inclusions and was completed alongside the analysis of the bricklaying and construction techniques [Table 1].

\begin{tabular}{|l|l|r|r|r|}
\hline Sample Number & Area & Size (cm) & $\begin{array}{l}\text { Macro- } \\
\text { fabric }\end{array}$ & Colour \\
\hline PA1 & E wall-central area & $50 \times 12$ & Fine & $10 \mathrm{R} 5 / 8$ \\
\hline PA2 & E wall-central area & $50 \times 12$ & Fine & $2.5 \mathrm{YR}$ \\
\hline & & & & $6 / 8$ \\
\hline PA3 & E wall-central area & $50 \times 12$ & Fine & $2.5 \mathrm{YR}$ \\
\hline & E wall-central area & & & $6 / 8$ \\
\hline PA5 & E wall-central area & $50 \times 12$ & Fine & $2.5 \mathrm{YR}$ \\
\hline & & & & $6 / 8$ \\
\hline PA6 & E wall-central area & $50 \times 12$ & Fine & $2.5 \mathrm{YR}$ \\
\hline & & & & $6 / 8$ \\
\hline PA7 & E wall-central area & $50 \times 11,5$ & Fine & $2.5 \mathrm{YR}$ \\
\hline & E wall-central area & & & $5 / 6$ \\
\hline
\end{tabular}




\begin{tabular}{|c|c|c|c|c|}
\hline PA9 & E wall-central area & $50 \times 11,5$ & Fine & $\begin{array}{r}2.5 \mathrm{YR} \\
5 / 6\end{array}$ \\
\hline PA10 & E wall-central area & $40 \times 12$ & Coarse & $\begin{array}{r}2.5 \mathrm{YR} \\
6 / 8\end{array}$ \\
\hline PA11 & E wall-central area & $50 \times 40 \times 12$ & Coarse & $\begin{array}{r}2.5 \mathrm{YR} \\
6 / 8\end{array}$ \\
\hline PA12 & E wall-central area & $50 \times 40 \times 12$ & Fine & $\begin{array}{r}2.5 \mathrm{YR} \\
6 / 8\end{array}$ \\
\hline PA13 & Top E wall-central internal area & $50 \times 40 \times 12$ & Fine & $\begin{array}{r}2.5 \mathrm{YR} \\
6 / 8\end{array}$ \\
\hline PA14 & Top E wall-central internal area & $50 \times 40 \times 12$ & Fine & $\begin{array}{r}2.5 \mathrm{YR} \\
6 / 8\end{array}$ \\
\hline PA15 & E wall-NE curved section & $50 \times 11,5$ & Coarse & $\begin{array}{r}2.5 \mathrm{YR} \\
6 / 8\end{array}$ \\
\hline PA16 & E wall-NE curved section & $50 \times 12$ & Fine & $\begin{array}{r}2.5 \mathrm{YR} \\
6 / 8\end{array}$ \\
\hline PA17 & E wall-NE curved section & $50 \times 12$ & Fine & $\begin{array}{r}2.5 \mathrm{YR} \\
6 / 8\end{array}$ \\
\hline PA18 & E wall-NE curved section & $49,5 \times 12$ & Fine & $\begin{array}{r}2.5 \mathrm{YR} \\
6 / 8\end{array}$ \\
\hline PA19 & E wall-NE curved section & $50 \times 12$ & Fine & $\begin{array}{r}2.5 \mathrm{YR} \\
6 / 8\end{array}$ \\
\hline PA20 & E wall-NE curved section & $50 \times 12$ & Fine & $\begin{array}{r}2.5 \mathrm{YR} \\
5 / 6\end{array}$ \\
\hline PA21 & E wall-NE curved section & $50 \times 12$ & Fine & $\begin{array}{r}2.5 \mathrm{YR} \\
5 / 6\end{array}$ \\
\hline PA22 & E wall-NE curved section & $50 \times 12$ & Fine & $\begin{array}{r}2.5 \mathrm{YR} \\
5 / 6\end{array}$ \\
\hline PA23 & E wall-NE curved section & $50 \times 12$ & Coarse & $\begin{array}{r}2.5 \mathrm{YR} \\
5 / 6\end{array}$ \\
\hline PA24 & E wall-NE curved section & $49 \times 12$ & Fine & $\begin{array}{r}2.5 \mathrm{YR} \\
5 / 6\end{array}$ \\
\hline
\end{tabular}




\begin{tabular}{|c|c|c|c|c|}
\hline PA25 & E wall-NE curved section & $50 \times 12$ & Fine & $\begin{array}{r}2.5 \mathrm{YR} \\
5 / 6\end{array}$ \\
\hline PA26 & E wall-NE curved section & $50 \times 12$ & Fine & $\begin{array}{r}2.5 \mathrm{YR} \\
5 / 6\end{array}$ \\
\hline PA27 & E wall-NE curved section & $50 \times 12$ & Fine & $10 \mathrm{R} 5 / 8$ \\
\hline PA28 & E wall-NE curved section & $50 \times 12$ & Fine & $10 \mathrm{R} 5 / 8$ \\
\hline PA29 & E wall-NE curved section & $50 \times 12$ & Coarse & $\begin{array}{r}2.5 \mathrm{YR} \\
5 / 6\end{array}$ \\
\hline PA30 & E wall-NE curved section & $50 \times 40 \times 12$ & Fine & $\begin{array}{r}2.5 \mathrm{YR} \\
6 / 8\end{array}$ \\
\hline PA31 & E wall-NE curved section & $50 \times 40 \times 11,5$ & Fine & $\begin{array}{r}2.5 \mathrm{YR} \\
6 / 8\end{array}$ \\
\hline PA32 & E wall-internal part & $50 \times 40 \times 12$ & Fine & $\begin{array}{r}2.5 \mathrm{YR} \\
6 / 8\end{array}$ \\
\hline PA33 & E wall- internal part & $50 \times 40 \times 11,5$ & Fine & $10 \mathrm{R} 5 / 8$ \\
\hline PA34 & E wall- internal part & $50 \times 40 \times 12$ & Fine & $10 \mathrm{R} 5 / 8$ \\
\hline
\end{tabular}

Table 1. Macroscopic analysis of the samples

\subsection{Microscopic Analysis}

Microscopic observations were carried out using portable X-Ray Fluorescence (pXRF), Scanning Electron Microscope (SEM) followed by Energy Dispersive X-Ray Microanalysis (SEM-EDS), and petrographic analysis. pXRF was performed in situ during the cutting of the 34 samples by Dr Andreas Charalambous of the Archaeological Research Unit of the University of Cyprus with a handheld pXRF Innov-X DELTA Premium model [FIG.8]. This method was selected because of its on-site application and its non-destructive nature. Limitations of the pXRF were carefully considered and included in the consideration of the results (Liritzis and Zacharias 2011; Lorenzon 2017; Shackley 2011).

\section{Figure 8}

The specific instrument was equipped with a $4 \mathrm{~W}, 50 \mathrm{kV}$ tantalum anode X-Ray tube and a highperformance Silicon Drift Detector (SDD) with a resolution of $155 \mathrm{eV}(\mathrm{Mo}-\mathrm{K} \alpha)$, covered by a 
20-mm detector window. Multiple measurements were taken for each spot, and the analysis was carried out in soil mode and each spot analysed for 80 seconds. All the readings were taken on the clean surface cut for the sampling. Standard reference material was used for calibration, while consistency within the samples was assessed by comparison with the geological study of the area (Zomeni 2012). Values of 24 elements (P, S, Cl, K, Ca, Ti, Cr, Mn, Fe, Co, Ni, Cu, $\mathrm{Zn}, \mathrm{As}, \mathrm{Zr}, \mathrm{Mo}, \mathrm{Pd}, \mathrm{Ag}, \mathrm{Cd}, \mathrm{Sn}, \mathrm{Sb}, \mathrm{Pt}, \mathrm{Au}$ and $\mathrm{Pb}$ ) were collected and recorded in ppm (part per million) and then exported in an excel file. Elements below detection or affected by postdepositional factors (e.g. $\mathrm{P}$ and $\mathrm{Cl}$ ) were not considered in the statistical analysis (Frankel and Webb 2012; Goodale et al. 2012; Hunt and Speakman 2015;). The eight elements selected (Co, $\mathrm{Ni}, \mathrm{Cr}, \mathrm{Fe}, \mathrm{Zn}, \mathrm{Zr}$, Ti and $\mathrm{Mn}$ ) are included in the statistical analysis for their reliability in pXRF, as evidenced in previous studies on their relevance in soil composition (Emery and Morgenstein 2007; Goodale et al. 2012; Morgenstein and Redmount 1998). Principal component analysis (PCA) and bivariate scatterplot were performed on the $\mathrm{pXRF}$ results with the R software (3.3.2) in order to provide data on continuity in the procurement of raw sources and manufacturing and construction phases.

The samples were extensively tested in the laboratory, performing granulometric analysis, SEM-EDS, and thin section petrography. Initially, the lithography of the sample was performed to record colour, inclusions and grain size analysis. Approximately 10gr of sample were subsamples to establish the ratio of clay, silt and sand through hydrometer analysis and wet sieving as referred by ASTM D422-63 (ASTM 2007; Costi de Castrillo, Philokyprou and Ioannou 2017; Love 2013). Error should be considered at 1-2\% of the measure estimated, taking into account both inaccurate readings and loss of sediment during the procedure. A selected number of samples were then subjected to SEM-EDS at the Wiener Laboratory (using a SEM JEOL JMS-IT300LV) for a more detailed analysis of binders and aggregates (Love 2017; Zhang et al. 2016), and to investigate the elemental composition of the mudbricks. Further investigation included petrographic analysis of the samples through thin section petrography using a polarized microscope Leica DM2700P (Nodarou, Frederick and Hein 2008).

\section{Results}

4.1. Macroscopic observations

The results of the macroscopic analysis of the Laona mudbricks indicate that they have a standardised size, $50 \times 40 \times 12 \mathrm{~cm}$ (slight differences in measurement, which vary between 49$50 \times 40 \times 11,5-12 \mathrm{~cm}$, are due to the shrinking of the bricks after manufacturing) and were 
produced with the use of a wooden mould as attested by the regular impressions on their lateral surface. Two bricklaying techniques are evident in the rampart, which attest to two distinct approaches to construction. The first consists of an irregular, so-called English bond (Wright 2005: 104), i.e. alternating headers and stretchers in different rows, and is mainly present in the East wall. The second technique consists of a running bond, which has been recorded in the NE curved section of the wall. The difference in bonding between these two parts of the wall could be related to their different architectural structure: the East wall was meant to be straight, while the NE wall develops curve. Macroscopic analysis of the fabric indicates an overall similarity of the bricks employed in both areas, not only in regard to their colour (Munsell 2.5 YR 6/8, 2.5 YR 5/6 and 10 R 5/8), but also their composition, which in all cases consists of yellowish-brown marly-clay with a small number of inclusions such as gravel (grain size $>2 \mathrm{~mm}$ ), pottery sherds and vegetal temper (i.e. chaff).

\subsection{Granulometric Analysis}

Granulometric analysis was performed through use of a hydrometer and wet-sieving to determine possible recipes of production. Samples were dried for several days in the laboratory, before microscopic observations were conducted with a stereoscopic microscope on the sieved fractions.

Granulometric results show that Laona mudbricks are characterized by a high percentage of sand and gravel (i.e. coarse fraction, usually more than $40 \%$ ) mixed with silt and clay (i.e. fine fraction). Stereoscopic analysis has determined the use of chaff as the main vegetal temper in mudbrick production, likely a by-product from agricultural practices (i.e. barley) [Fig.9]. Initially, two different groups of mudbricks were separated based on their coarse and fine fraction percentages [Table 2, Figs. 10-11].

\section{Figure 9}

\begin{tabular}{|l|l|l|l|l|r|l|r|}
\hline Sample & $\begin{array}{l}\text { Clay } \\
\mathbf{( \% )}\end{array}$ & $\begin{array}{l}\text { Silt } \\
\mathbf{( \% )}\end{array}$ & $\begin{array}{l}\text { Sand } \\
\mathbf{( \% )}\end{array}$ & $\begin{array}{l}\text { Gravel } \\
\mathbf{( \% )}\end{array}$ & $\begin{array}{l}\text { Fine } \\
\text { Fraction }\end{array}$ & $\begin{array}{l}\text { Coarse } \\
\text { Fraction }\end{array}$ & $\begin{array}{l}\text { Vegetal } \\
\text { Temper }\end{array}$ \\
\hline PA1 & 21.75 & 22.75 & 55.5 & 0 & 44.5 & 55.5 & None \\
\hline PA2 & 14.29 & 28.57 & 57.14 & 0 & 42.86 & 57.14 & $10 \%$ \\
\hline PA3 & 8.75 & 22.5 & 40.3 & 28.45 & 31.25 & 68.75 & $10 \%$ \\
\hline PA4 & 11.43 & 28.57 & 60 & 0 & 40 & 60 & $10 \%$ \\
\hline
\end{tabular}




\begin{tabular}{|c|c|c|c|c|c|c|c|}
\hline PA5 & 7.5 & 30 & 62.5 & 0 & 37.5 & 62.5 & $10 \%$ \\
\hline PA6 & 12.5 & 30 & 57.5 & 0 & 42.5 & 57.5 & $10 \%$ \\
\hline PA7 & 8.75 & 16.25 & 53 & 22 & 25 & 75 & $10 \%$ \\
\hline PA8 & 14.29 & 14.29 & 71.42 & 0 & 28.58 & 71.42 & $10 \%$ \\
\hline PA9 & 3.33 & 13.33 & 63.3 & 20.04 & 16.66 & 83.34 & $10 \%$ \\
\hline PA10 & 16.67 & 33.33 & 50 & 0 & 50 & 50 & $10 \%$ \\
\hline PA11 & 18.75 & 18.75 & 62.5 & 0 & 37.5 & 62.5 & $30 \%$ \\
\hline PA12 & 18.18 & 9.09 & 72.73 & 0 & 27.27 & 72.73 & $30 \%$ \\
\hline PA13 & 6.25 & 12.5 & 59.2 & 22.05 & 18.75 & 81.25 & $30 \%$ \\
\hline PA14 & 11.11 & 22.22 & 66.67 & 0 & 33.33 & 66.67 & $30 \%$ \\
\hline PA15 & 17.33 & 2.67 & 67 & 13 & 20 & 80 & $40 \%$ \\
\hline PA16 & 22.22 & 11.11 & 66.67 & 0 & 33.33 & 66.67 & $10 \%$ \\
\hline PA17 & 11.76 & 29.41 & 58.83 & 0 & 41.17 & 58.83 & $10 \%$ \\
\hline PA18 & 18.75 & 25 & 56.25 & 0 & 43.75 & 56.25 & $10 \%$ \\
\hline PA19 & 12.99 & 22.08 & 50.3 & 14.63 & 35.07 & 64.93 & $10 \%$ \\
\hline PA20 & 12 & 32 & 56 & 0 & 44 & 56 & $40 \%$ \\
\hline PA21 & 31.5 & 32 & 36.5 & 0 & 63.5 & 36.5 & $40 \%$ \\
\hline PA22 & 24.51 & 31.37 & 44.12 & 0 & 55.88 & 44.12 & $30 \%$ \\
\hline PA23 & 14.55 & 12.73 & 50.5 & 22.22 & 27.28 & 72.72 & $20 \%$ \\
\hline PA24 & 16.67 & 25 & 48 & 10.33 & 41.67 & 58.33 & $20 \%$ \\
\hline PA25 & 13.5 & 20 & 66.5 & 0 & 33.5 & 66.5 & $20 \%$ \\
\hline PA26 & 11.29 & 36.29 & 52.42 & 0 & 47.58 & 52.42 & $20 \%$ \\
\hline PA27 & 11.15 & 22.76 & 52.9 & 13.19 & 33.91 & 66.09 & $20 \%$ \\
\hline PA28 & 39.99 & 22.27 & 37.74 & 0 & 62.26 & 37.74 & $20 \%$ \\
\hline PA29 & 14.52 & 30.65 & 54.83 & 0 & 45.17 & 54.83 & $20 \%$ \\
\hline PA30 & 10 & 35 & 55 & 0 & 45 & 55 & $20 \%$ \\
\hline PA31 & 15.38 & 26.92 & 57.68 & 0.02 & 42.3 & 57.7 & $20 \%$ \\
\hline PA32 & 8.33 & 33.33 & 50.2 & 8.14 & 41.66 & 58.34 & $20 \%$ \\
\hline PA33 & 12.62 & 33.98 & 53.4 & 0 & 46.6 & 53.4 & $20 \%$ \\
\hline PA34 & 8.89 & 13.33 & 60.4 & 17.38 & 22.22 & 77.78 & $20 \%$ \\
\hline
\end{tabular}

Table 2. Granulometric analysis 


\section{Figure 10}

\section{Figure 11}

The distribution of fine and coarse fractions shows at least two recipes for mudbrick production, indicating that mudbricks superficially similar in colour, macro-inclusions and size may have different grain size percentages. The groups identified through granulometric analysis are the following:

- Group 1 is characterised by a higher percentage of sand (coarse fraction more than $60 \%$ ); PA3, PA5, PA7, PA8, PA9, PA11, PA12, PA13, PA14, PA15, PA16, PA19, PA23, PA25, PA27 and PA34.

- Group 2 is characterised by a higher fine fraction: PA1, PA2, PA4, PA6, PA10, PA17, PA18, PA20, PA21, PA22, PA24, PA26, PA28, PA29, PA30, PA31, PA 32, and PA33.

This result could indicate either the presence of different manufacturing teams working at the same time or different production times for the mudbricks. Thus, to investigate this issue further geochemical analyses of the two groups were undertaken to determine and better understand specific patterns of manufacture and consumption.

\subsection{Geochemical results}

The results of the pXRF analysis (see Table 3) and the trends in the chemical data were analysed through Principal Component Analysis (PCA) and bivariate statistical analysis to shed light on geochemical groups and a possible classification based on chemical fingerprints.

Table 3. pXRF results (see attached pdf)

The PCA was performed on eight variables using as discriminant the rampart sampling areas. The raw data has been normalised in $\mathrm{R}$ and the confidence ellipse has been calibrated at $95 \%$ with the two main Principal Components (PC1 and PC2) explaining $78.9 \%$ of the total variability. The PCA shows all the samples collected from different parts of the wall structure, presenting a tight cluster of points, which supports the hypothesis of a common source of raw material procurement [Fig.12].

\section{Figure 12}


Bivariate analysis based on the variability of $\mathrm{Fe}$ and $\mathrm{Mn}$ within the mudbrick recipe indicates different mudbrick clusters within the same structure. Four chemical clusters were identified in the bivariate scatterplot that point to distinctive production batches [Fig.13].

\section{Figure 13}

The four clusters are comprised of mudbricks which have similar percentages of Manganese and Iron, thus supporting their production during the same manufacturing event with the same type of soil. Consistency in the PCA and bivariate analysis was determined by comparison with the local geological analysis of the area (Zomeni 2012). Additionally, the SEM-EDS analyses on selected mudbrick samples from both the East and North-East wall confirm the presence of illite, kaolinite and calcite in the matrix to create the best workable recipe; morphologically, it shows the consistent presence of a compressed and compacted matrix, which results from the manufacturing technique of pressing the mud mixture into the mould. The chemical spectra reflect a high quartz concentration as well as the presence of Wollastonite, a key component of calcite and pyroxenes, which are present in the marly-clay sediments around Palaepaphos and may work as natural stabiliser alongside sand (Liberotti and Quaresima 2010) [Fig.14]. The small number of pores and cracks in the matrix of the mudbricks results from the limited presence of vegetal temper, the activity of biological agents and progressive evapotranspiration linked to water erosion.

\section{Figure 14}

The geochemical analysis of the sample performed through SEM-EDS highlights a strong consistency of raw material sources among the different batches of bricks identified through grain size and pXRF analysis [Fig.15].

\section{Figure 14}

\section{Figure 15}

\subsection{Petrographic results}

Petrographic analysis shows the presence of a single mudbrick fabric with two distinct subfabric groups within the 34 samples collected. The Palaepaphos mudbrick fabric is quite standardised and characterised by a light-brown colour and numerous poorly-sorted inclusions. 
Both sub-fabrics are characterised by a bimodal distribution of medium to fine sand elements with small, even equant particles of other grain sizes (clay-silt). The distinction between the two sub-fabrics is based on the average number of inclusions present: sub-fabric 1A contains at least $40 \%$ inclusions, while sub-fabric $1 \mathrm{~B}$ has only $10 \%$ of inclusions [Fig.16].

\section{Figure 16}

Most of the inclusions in both sub-fabrics are comparable, being equant, rounded to sub-rounded, with a frequency from common to dominant. The inclusions detected are quartz, olivine, pyroxene, chlorite, iron oxides nodules and clay pellets, and, in lesser numbers, sandstone fragments, charcoal and calcite [Fig.18a and b]. Numerous microfossils have been identified, such as foraminifera (i.e. globular planktic foraminifer), radiolarian and bioclast fragments, which occur naturally in the Palaepaphos deposits of marine limestone (Zomeni 2012) [Fig.18c]. Several clasts are surrounded by a continuous clay coating, creating a rolling pedofeature around the clast (i.e. PA 23) [Fig.18d]. The mapping of the two sub-fabrics against the chemical analysis highlights their chemical consistency. The similarity of their fabric is differentiated only by the size and percentage of the inclusions [Fig.17].

\section{Figure 17}

The limited number of voids suggests a conservative use of vegetal temper. In fact, the elongated voids usually associated with vegetal temper are rare in all the samples analysed. Vesicular voids and micro-fissures were also recorded and associated with multiple activities, including progressive evapotranspiration and thawing during production and cracking during the drying process (Cammas 2018; Friesem 2014) [Fig.18d].

\section{Figure 18}

\section{Discussion}

The granulometric and petrographic analyses of the 34 samples have identified the presence of two groups that relate to different practices followed in the manufacturing of the Laona mudbricks (e.g. the use of sand as temper). As in earthen architecture elsewhere, sediments with a high clay content were degreased by using sand in the mixture (Minke 2006: 39-40) to prevent cracking. This is reflected in the two groups identified in both the granulometric 
analysis, and the petrography: sub-fabric 1A corresponds with granulometric group 1 and subfabric 1B with granulometric group 2. These small deviations of the local mudbrick recipe highlight a direct connection between the built and natural environment as they indicate that the builders were able to adapt traditional manufacturing practices to the resources that were to hand. Mineralogical analyses, for example, document the specific use of locally-available sand as temper when chaff was unavailable or not available in sufficient quantities.

The results also indicate that the Laona mudbricks, despite being produced with a similar recipe, were manufactured in multiple batches, which are easily distinguished based on grain size ratio and the amount and/or type of temper in the mixture. The marly-clay nature of the bricks makes the high sand percentage in one of the two macro-groups, identified during grain size analysis [Figs. 10 and 11], particularly noticeable as not typical of ancient production. The quantity of sand is within the margins suggested in earthen architecture manuals (Minke 2006: 65-66; Olivier 2008: 102), as sand likely constituted an easily-available degreaser alongside chaff, and one which was available all year around. Local availability may have influenced the selection of sand as the preferred temper to prevent shrinking and fissuring in the marly-clay mudbricks (Aurenche 1981: 51-52; Lorenzon 2017: 194; Minke 2006: 39). These data point to different manufacturing practices that can be affected by seasonal changes (i.e. drought) and/or multiple groups of builders involved in the production of the mudbricks. However, the mudbricks of different granulometry are widely spread between the two sections of the wall from where the samples were taken, and they are located both near the preserved top and also close to the currently excavated bottom. This distribution pattern weakens the case of multiple phases in the construction of the rampart and strengthens the presence of multiple groups working for the production of the mudbricks.

The SEM-EDS results combined with the $\mathrm{pXRF}$ analysis indicate a comprehensive consistency in the raw material sources used for all the mudbricks and, also, in the types of degreasers, which include only sand and a limited presence of chaff. The use of sand as the predominant temper in the production of the Laona mudbricks is also supported by the SEM, which shows a high quantity of sand quartz in a number of samples [Fig.16].

Although PCA analysis shows consistency in local raw source procurement, the bivariate plot of Iron and Manganese values indicates at least four mudbrick production events, represented in the four geochemical groups of the Laona samples. These results further support the 
hypothesis of multiple manufacturing groups using the same raw sources but 'personalising' the recipes by sampling a different part of the quarry and then also adding a different temper. Evidently, the same sources were quarried multiple times in order to collect enough material to produce the required number of mudbricks for the construction of the Laona rampart. The granulometry, the arrangement of the mudbricks in the wall, shows that mudbricks from different geochemical groups, probably produced by different teams, were laid down together. This points to a single construction event, which is well exemplified, for instance, by the chemical similarities between PA 34, PA 32, PA 21 and PA 33. These mudbricks were manufactured at the same time within the same bunch, yet PA 34, PA32 and PA33 were used in the internal central part of the wall and PA21 in the external NE curved section of the wall. The same dissemination pattern is observed with mudbricks which belong to the other three geochemical groups: geochemically similar mudbricks are found next to each other, but also in different sections of the wall both in the internal and external face. It is, therefore, evident that the mudbricks were not produced for immediate consumption; they were manufactured, stored and then used for a single construction event. This suggests a well-organised, centrallymanaged building process, which involved a large supply of workers (probably working in small groups), and a well-coordinated storage and use of structural materials.

Although the rampart is considered a single construction event, differences in bricklaying techniques used in the E wall (the irregular so-called English bond) and the NE curved section of the wall (regular running bond), in conjunction with the results of the geoarchaeological analysis, suggest the presence of multiple construction teams within the same cohesive architectural project. In this context, repairs of eroded or broken mudbricks that would have taken place at a later stage would be visible macroscopically on the external surface of the wall by fissures created by evapotranspiration, and microscopically by the presence of different petrographic fabric. However, repairs, which would have made a clear dissonance within the wall fabric, have not been attested. The short life-span of the rampart, which had already been abandoned when the mound was constructed in the 3rd century BCE, may have required a limited degree of repair work. Although the mud plastering of the exposed mudbrick surfaces would have been regularly renewed during the period of use, no evidence of plaster was found on the mudbricks during their excavation. This observation highlights an unknown episode that must have forced the local authorities to give up on the regular upkeep of the rampart. Consequently, its abandonment and gradual deterioration had occurred before the decision to 
use Laona for the construction of a very different, and even more labour demanding, monument: the tumulus.

\section{Conclusions}

This pilot study has shed light on earthen architecture practices in relation to a recently discovered public monument that was built in the Cypro-Classical period, almost certainly around 500 BCE. Mineralogical, geochemical and archaeological data have been combined to investigate manufacturing and construction events, and they have provided manufacturing recipes and motivational choices regarding raw material selection - such as the use of sand as degreaser. Macroscopic and microscopic data, on the other hand, led to the identification of the different steps in the chaîne opératoire from raw source collection to construction techniques.

The manufacture of the required quantity of the mould-made mudbricks was evidently linked to a centrally organised form of production and was carried out by multiple teams of local workmen. A similar earthen architectural narrative is known from other islands in the Mediterranean (Lorenzon 2017). Distinct local traditions have also been confirmed in the case of the Laona earthen architecture. The use of a stone socle and a mudbrick superstructure (Demetriou et al. 2003; Wright 2000, 22) may be superficially similar to Near Eastern building techniques, but it also differentiates the Cypriote tradition from Anatolian and Aegean building practices, where wooden elements were employed as a supporting framework on stone socles.

The pilot study has also highlighted a well-coordinated and successfully implemented building project of circa $500 \mathrm{BCE}$. Fortifications tend to have very long lives, but in this particular case, despite the investment in materials and human labour, the combined data reveal that the monument had a relatively short life span; apparently, it was abandoned sometime in the fourth c. BCE. The reasons that led to its abandonment may be revealed as the excavations continue. Once archaeological data had confirmed the date of the initiation of the building project, there was no difficulty in identifying who must have been responsible for building the Laona rampart: it had to have been one of the basileis (kings) of the Paphian city-state; their rule is amply attested by textual data from the beginning of the seventh to the end of the fourth centuries BCE (cf. Iacovou 2006).

To this day, however, we have rarely had the chance to link the material remains of stateendorsed building project to a local workforce. This pilot study has shown that the techniques employed during the production and construction of the mudbricks highlight intimate 
traditional knowledge and expertise of local builders. Consequently, the most compelling aspect of this research is the establishment of mudbrick as a powerful source of information on the social and cognitive aspects of monumental architecture in the archaeology of Cyprus, in particular in the context of a complex socio-economic system.

We hope that this pilot study has demonstrated the importance of introducing a geoarchaeological methodology alongside building archaeology in the investigation of mudbrick manufacturing and construction practices from excavation contexts. In seeking to understand the development of earthen architecture and the relationship between the natural and the built environment, this methodology offers a strong potential that has been proven successful in this particular case study.

\section{Acknowledgements}

This research was made possible due to funding received from the AG Leventis Foundation following the successful assessment of our application submitted to the competitive AG Leventis Foundation University of Cyprus research programmes for 2017-2019. Many colleagues and early stage researchers, most of whom have been loyal members of PULP since its initiation, have offered their assistance and expertise during this pilot study. We wish to thank in particular Associate Professor Kyriakos Themistokleous and Dr Athos Agapiou of the Eratosthenes Research Centre, Cyprus University of Technology (CUT), and Dr Andreas Charalambous, Dr Stella Diakou, Dr Artemis Georgiou, Rafael Soler and Dr Jacopo Tabolli of the Archaeological Research Unit, University of Cyprus (UC). We also extend sincere thanks to Senior Geological Officer Dr Zomenia Zomeni of the Geological Survey Department, whose doctoral dissertation is devoted to the Geoarchaeology of Palaepaphos, and to the Department of Lands of Surveys of the Republic of Cyprus for the steadfast support of PULP with invaluable digital data. In addition, Maria Iacovou wishes to thank Dr Panagiotis Karkanas, Director of the Wiener Laboratory for Archaeological Science (ASCSA), for bringing to her attention the work of Marta Lorenzon and for inviting us to use the facilities of the Wiener Laboratory where most of the analyses of MEANING 2017-2019 have been conducted.

Finally, we wished to thank the anonymous reviewers for their insightful comments and suggestions. 


\section{References}

ASTM, 2007. Standard test method for particle-size analysis of soils. ASTM Stand. Test Method. http://dx.doi.org/10.1520/D0422-63R07E01.2.

Aurenche, O. 1981. La maison orientale. L'architecture du Proche Orient ancien dès origines au milieu du quatrième millénaire. Vol I-III (BAH 109). Paris.

Cammas, C. 2018. Micromorphology of earth building materials: Toward the reconstruction of former technological processes (Protohistoric and Historic Periods). Quaternary International 483, pp. 160-179.

Clarke, J. 2007. Site Diversity in Cyprus in the Late 5th Millennium cal. BC: Evidence from Kalavasos Kokkinoyia. Levant 39:1, pp. 13-2.

Costi de Castrillo, M., Philokyprou, M., Ioannou, I. 2017. Comparison of adobes from prehistory to-date. Journal of Archaeological Science: Reports: 12, pp. 437-448.

Demetriou, T., Pattiches, A., Konstantinides, A., Papadoures, G. 2003. Restoration and Maintenance of Traditional Settlements. Cyprus Civil Engineers and Architects Association: Nicosia.

Emery, V. L., Morgenstein, M. 2007. Portable EDXRF Analysis of a Mud Brick Necropolis Enclosure: Evidence of Work Organization, El Hibeh, Middle Egypt. Journal of Archaeological Science 34, pp. 111-22.

Frankel, D., Webb, J.M. 2012. Pottery production and distribution in prehistoric Bronze Age Cyprus. An application of pXRF analysis. Journal of Archaeological Science 39:5, pp. 1380 1387.

French, C. A. I. 1984. A sediments analysis of mud brick and natural features at el-Amarna. In Barry J. Kemp (ed) Amarna Reports I. Occasional Papers 1. Vol. I. pp. 189-201. London: Egypt Exploration Society.

Friesem, D. E., Boaretto, E., Eliyahu-Behar, A., Shahack-Gross, R. 2011. Degradation of mud brick houses in an arid environment: a geoarchaeological model. Journal of Archaeological Science 38:5, pp. 1135-1147.

Friesem, D. E., Karkanas, P., Tsartidou, G., Schahack-Gross, R. 2014. Sedimentary processes involved in mud brick degradation in temperate environments: a micromorphological 
approach in an ethnoarchaeological context in northern Greece. Journal of Archaeological Science 41, pp. 556-567.

Ginns, A. 2015. The 2015 Season of Excavation at Kurgus. Sudan and Nubia 19, pp. 132142.

Goldberg, P. 1979. Geology of Late Bronze Age mudbrick from Tel Lachish. Tel Aviv 6:1-2, pp. 60-67.

Goodale, N., Bailey, D.G., Jones, G.T., Prescott, C., Scholz, E., Stagliano, N., Lewis, C. 2012. pXRF: a study of inter-instrument performance. Journal of Archaeological Science 39:4, pp. 875-883.

Hermary, A. 2014. Les foncions sacerdotales des souverains chypriotes. In M. Hatzopoulos and M. Iacovou (eds.), Basileis and Poleis on the Island of Cyprus: The Cypriote Polities in Their Mediterranean Context. Proceedings of a Symposium held in Nicosia in 2012. Cahier du centre d'études chypriotes, pp.137-152.

Hunt, A. M. W., Speakman, and R. J. 2015. Portable XRF analysis of archaeological sediments and ceramics. Journal of Archaeological Science 53, pp. 626-638.

Iacovou, M. 2006. The Basileus in the Kingdoms of Cyprus. In S. Deger-Jalkotzy and I. S. Lemos (eds), Ancient Greece from the Mycenaean Palaces to the Age of Homer, Edinburgh Leventis Studies 3. Edinburgh: University of Edinburgh. 315- 35.

Iacovou, M. 2008. The Palaepaphos Urban Landscape Project: Theoretical Background and Preliminary Report 2006-2007. Report of the Department of Antiquities, Cyprus, pp. 263289.

Iacovou, M. 2012. From regional gateway to Cypriot kingdom: copper deposits and copper routes in the chora of Paphos. In V. Kassianidou - G. Papasavvas (ed.) Eastern Mediterranean Metallurgy and Metalwork in the Second Millennium BC. A Conference in Honour of James D. Muhly, Oxford/Oakville, pp. 58-69.

Iacovou, M. 2013a. Paphos before Palaepaphos. New approaches to the history of the Paphian kingdom. In D. Michaelides (ed.) Epigraphy, Numismatics, Prosopography and History of Ancient Cyprus. Papers in Honour of Ino Nicolaou [SIMA Pocket-book 179], Uppsala, pp. 275-291. 
Iacovou, M. 2013b. The Cypriot syllabary as a royal signature. The political context of the syllabic script in the Iron Age. In P. Steele (ed.), Syllabic Writing on Cyprus and its context, Cambridge: Cambridge University Press, pp. 133-52.

Iacovou, M. 2014. Political economies and landscape transformations. The case of ancient Paphos. In J.M. Webb (eds.) Structure, Measurement and Meaning: Insights into the Prehistory of Cyprus. Studies on Prehistoric Cyprus in Honour of David Frankel [SIMA 143], Uppsala, pp. 161-174.

Iacovou, M. 2017a. 2016. The tumulus of Palaepaphos-Laona. From identification to method

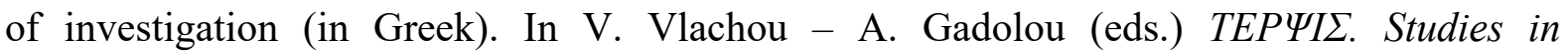
Mediterranean Archaeology in Honour of Nota Kourou [CReA-Patrimoine Etudes d'archeologie 10], Brussels, pp. 307-319.

Iacovou, M. 2017b. Traces of a lost memory: new evidence for the city-kingdom of Ancient Paphos (in Grek). In N. Papademetriou - M. Toli (eds), Ancient Cyprus. Recent developments in the archaeology of the eastern Mediterranean, Museum of Cycladic Art, Athens, pp. 189214.

Iacovou M., Stylianidis, E., Sarris A., Agapiou, A. 2009. A long-term response to the need to make modern development and the preservation of the archaeo-cultural record mutually

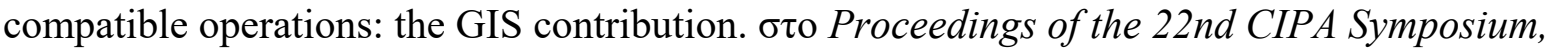
Kyoto, Japan, 11-15 October 2009.

(https://www.ucy.ac.cy/ariel/documents/Publications/A_LONGTERM_

\section{RESPONCE 2009.pdf)}

Illampas, R., Ioannou, I., Costi de Castrillo, M., Theodosiou, A. 2011. Earthen Architecture in Cyprus. In: Correia, M., Dipasquale, L., Mecca, S. (Eds.) Terra Europae. Earthen Architecture in European Union, pp. 97-99. Edizioni ETS, Pisa.

Jerome, P., Chiari, G., Borelli, C. 1999. The architecture of mud: Construction and repair technology in the Hadhramaut region of Yemen. Association for Preservation Technology International Bulletin 30, pp. 39-48.

Knapp A. B. 2013. The Archaeology of Cyprus: From Earliest Prehistory through the Bronze Age. New York: Cambridge University Press.

Liberotti, G., Quaresima, R. 2010. Building materials in the 4th and early 3rd millennium monumental architecture at Arslantepe: mudbricks and plaster, in Frangipane, M. (ed.), 
Economic centralization in Formative States. The archaeological reconstruction of the economic system the 4th millennium Arslantepe, pp.73-80. Roma: Università di Roma "La Sapienza".

Liritzis, I., Zacharias, N. 2011. Portable XRF of Archaeological Artifacts: Current Research, Potentials and Limitations. In M. Steven Shackley (ed.) X-Ray Fluorescence Spectrometry $(X R F)$ in Geoarchaeology, pp. 109-142. New York: Springer, New York.

Lorenzon, M. 2017. Earthen Architecture in Bronze Age Crete. From raw materials to construction. PhD Thesis. University of Edinburgh.

Love, S. 2012. The Geoarchaeology of Mudbricks in Architecture: A Methodological Study from Çatalhöyük, Turkey. Geoarchaeology 27, pp. 140-56.

Love, S. 2013. An archaeology of mudbrick houses from Çatalhöyük. In Hodder, I. (Ed.)

Substantive Technologies at Çatalhöyük: Reports from the 2000-08 Seasons. Cotsen Institute of Archaeology, Los Angeles, pp. 81-96.

Love, S. 2017. Field Methods for the Analysis of Mud Brick Architecture. Journal of Field Archaeology 42:4, pp. 351-363.

Karkanas, P., Goldberg, P. 2019. Reconstructing Archaeological Sites. Understanding the Geoarchaeological Matrix. Oxford: Wiley Blackwell.

Maier, F.G. 1989. Priest Kings in Cyprus. In E. Peltenburg, (ed.) Early Society in Cyprus, Edinburgh, 76-391.

Minke, G. 2006. Building with earth: design and technology of a sustainable architecture. Basel: Birkhäuser.

Morgenstein, M. E., Redmount, and C. A. 1998. Mudbrick Typology, Sources, and Sedimento- logical Composition: A Case Study from Tell El-Muqdam, Egyptian Delta. Journal of the American Research Center in Egypt 35, pp. 129-46.

Munsell Color. 1929. Munsell student chart. Baltimore, Md.: Munsell Color.

Nodarou, E., Frederick C., Hein, A. 2008. Another (mud)brick in the wall: scientific analysis of Bronze Age earthen construction materials from East Crete. Journal of Archaeological Science 35, pp. 2997-3015.

Oliver, A. 2008. Modified Earthen Materials, in E. Avrami, H. Guillaud and M. Hardy (eds.) Terra Literature Review, p. 96-107. Los Angeles: Getty Conservation Institute. 
Peltenburg, E. 1978. The Sotira Culture: regional diversity and cultural unity in Late Neolithic Cyprus. Levant 10, pp. 55-74.

Philokyprou, M. 1998. Building Materials and Structures of Cyprus Architecture: From the Neolithic Period to the Late Chalcolithic Period. University of Cyprus. PhD dissertation. Philokyprou, M. 2012. The Beginnings of Pyrotechnology in Cyprus, International Journal of Architectural Heritage 6:2, pp. 172-199.

Rosen, A. M. 1986. Cities of Clay: The Geoarchaeology of Tells. Chicago- London: The University of Chicago Press.

Satraki, A. 2012. Cypriot Kings from Kosmaso to Nikokreon (in Greek). Athens: Archaiognosia.

Shackley, M.S. 2011. An introduction to x-ray fluorescence (XRF) analysis in geoarchaeology. In: Shackley, M.S. (Ed.) X-Ray Fluorescence Spectrometry (XRF) in Geoarchaeology. Springer, New York, USA, pp. 7-44.

Thomas, G. 1995. Prehistoric Cypriot Mud Buildings and their Impact on the Formation of Archeological Sites. PhD Thesis. University of Edinburgh.

Todd, I. A. 1979. Vasilikos Valley Project: Third Preliminary Report, 1978. Journal of Field Archaeology 6:3, pp. 265-300, DOI: 10.1179/009346979791489258

Wright, G.R.H. 1992. Ancient Building in Cyprus. Leiden; New York: Brill.

Wright, G.R.H. 2000. Ancient Building Technology. Historical background. Leiden: Brill. Wright, G.R.H. 2005. Ancient Building Technology. Materials. Volume 1-2. Leiden: Brill. Zomeni, Z. 2012. Quaternary Marine Terraces on Cyprus: Constraints on Uplift and Pedogenesis, and the Geoarchaeology of Palaipafos. Unpublished PhD Dissertation, Oregon State University.

Zhang, Y., Jia, L.T., Mei, H., Cui, Q., Zhang, P.G., Sun, Z.M. 2016. Fabrication, microstructure and properties of bricks fired from lake sediment, cinder and sewage sludge. Construction and Building Materials 121, pp. 154-160. 


\section{LEGENDS of ILLUSTRATIONS}

FIG.1: The hydrological basin of Paphos indicating the main rivers and the Paphos forest (Data source: Geological Survey Department)

FIG 2: Orthophoto map of the modern community of Kouklia, indicating archaeological sites mentioned in the text (Data source: Department of Lands and Surveys)

FIG.3: Photorealistic representation of the northwest side of the Laona tumulus based on a UAV (unmanned aerial vehicle) campaign (PULP +Eratosthenes Research Centre, CUT).

FIG.4: Ground plan of Laona indicating the rampart and the excavation squares in the SE quarter of the mound (background: UAV orthomosaic, Eratosthenes Research Centre, CUT).

FIG.5: The two facing staircases of the rampart during excavation of the foundation trench in 2016 (PULP 2016).

FIG.6: The mudbricks at the highest preserved section of the rampart (113.086m asl.) at the northernmost excavated section (PULP 2018).

FIG.7: Ground plan of the excavated SE quarter of the mound showing the East and NorthEast section of the rampart (Raphael Soler for PULP 2018).

FIG.8: pXRF performed on the NE curved section of the mudbricks (PULP 2016)

FIG.9: Chaff impression on sample PA 16.

FIG 10: Granulometric analysis

FIG.11: Fine-Coarse fraction. Fine fraction comprises clay and silt, while coarse fraction includes sand and gravel.

FIG.12: PCA discriminated based on wall areas 
FIG.13: Scatterplot Fe vs Mn

FIG.14: SEM of mudbrick fabric (PA22 and PA25)

FIG.15: SEM-EDS graph photo, Sample PA25

FIG.16: Sub-fabric 1a (PA 25) and sub-fabric 1b (PA 6) in crossed nicols.

FIG. 17: PCA discriminated based on petrofabric groupings.

FIG.18: Thin section in crossed nicols. Top a and $b$. Mudbrick fabric with visible voids caused by thawing activities and inclusions such as quartz, plagioclase and pyroxene. Bottom c. Foraminifera in the mudbrick fabric. d. Details of rolling pedofeature. 